\title{
"ESTO ESTÁ PERDIDO, ES LA CASA DE BABILONIA»: MUJERES, NORMATIVIDAD Y CONTROL. LA VISITA DE PEDRO ANTONIO BARROETA AL MONASTERIO DE LA CONCEPCIÓN (1754)*
}

\author{
POR \\ LILIANA PÉREZ MIGUEL ${ }^{1}$ \\ Pontificia Universidad Católica del Perú
}

\section{RESUMEN}

Si bien es notoria la existencia de diversos estudios relativos a las instituciones religiosas y a su normativa en la monarquía hispánica, los actores involucrados, sin embargo, han sido un asunto que frecuentemente se ha dejado de lado. El presente trabajo quiere observar el proceso de creación de normatividad eclesiástica para el control y gobierno de los monasterios limeños femeninos en el siglo XVIII, prestando una especial atención al rol desempeñado tanto por las autoridades eclesiásticas como por las profesas mismas, que, lejos de ser meras receptoras de las disposiciones, constituyeron una pieza esencial para su construcción. Este análisis se realizará principalmente a partir de la visita general a los monasterios femeninos limeños, más concretamente al de la Concepción, efectuada por el arzobispo Pedro Antonio Barroeta y Ángel en 1754.

PALABRAS CLAVE: normatividad; derecho canónico; visita arzobispal; Pedro Antonio Barroeta y Ángel; monasterio de la Concepción; profesas; abadesa; monjas de clausura.

\section{"THIS IS LOST, IT IS THE HOUSE OF BABYLON": WOMEN, NORMATIVITY AND CONTROL IN LIMA. THE VISIT OF PEDRO ANTONIO BARROETA TO THE CONCEPTION MONASTERY (1754)}

\begin{abstract} Ángel in 1754. nun; abbess; cloistered nuns. 207-220. https://doi.org/10.3989/hs.2021.018

Recibido/Received 26-01-2020

Aceptado/Accepted $\quad 04-08-2020$
\end{abstract}

While there has been significant interest in the religious institutions of Imperial Imperial Spain and it's legislation, less studies have focused on the professed nuns as historical actors. The present paper examines the creation of ecclesiastical regulations for the control and government of the female Lima monasteries in the 18th century, paying special attention to the role played by both the ecclesiastical authorities and the professed nuns themselves, who far from being mere recipients of Church regulations, constituted an essential piece for the creation of the same. This analysis draws on an examination of the visita general to the Lima female monasteries, more specifically that of the Conception Monastery carried out by the archbishop Pedro Antonio Barroeta y

KEY WORDS: normativity; canonic law; archiepiscopal visit; Pedro Antonio Barroeta y Ángel; Conception Monastery; professed

Cómo CitAR eSte ARtículo / CitATion: Pérez Miguel, Liliana. 2021. «"Esto está perdido, es la casa de Babilonia”: mujeres, normatividad y control. La visita de Pedro Antonio Barroeta al monasterio de la Concepción (1754)». Hispania Sacra LXXIII, 147:

* Para finalizar la presente investigación he sido beneficiaria de un fondo de ayuda del Departamento de Humanidades de la Pontificia Universidad Católica del Perú. Asimismo, agradezco a José Luis Rodríguez Toledo por su trabajo con parte de los materiales utilizados y a Laura Gutiérrez, directora del Archivo Arzobispal de Lima y Melecio Tineo por su apoyo.

1 perezm.liliana@gmail.com / ORCID iD: https://orcid.org/0000-0002-0553-1703 


\section{INTRODUCCIÓN}

En 1756 el virrey don José Antonio Manso de Velasco, conde de Superunda, escribía una carta al rey en la que le informaba, entre otros asuntos, sobre los desórdenes relacionados con las comunidades religiosas femeninas de Lima. En su misiva señalaba que «... las recoletas son muy observantes y no hay que reformarlas, pero los que llaman conventos grandes, son una especie de pequeñas repúblicas donde la obediencia es voluntaria y la pobreza la posee la que no puede adquirir....$^{2}$ Dicho testimonio es sumamente revelador acerca de la percepción de las autoridades sobre los problemas existentes en los denominados grandes monasterios capitalinos, como la falta de control y la ausencia de la debida austeridad.

Las particulares características y composición de estas instituciones supusieron un gran reto para las autoridades civiles y para las eclesiásticas, encargadas estas últimas de velar por su correcto desempeño. En no pocas ocasiones se percataron de que la legislación vigente, basada en las disposiciones conciliares, sinodales o en las reglas propias de cada orden, era a todas luces insuficiente. Así, con el objetivo de imponer el debido orden en los monasterios de los territorios americanos, utilizaron las herramientas de las que disponían, como las visitas arzobispales, los autos reguladores y la temida excomunión.

El presente artículo profundiza en la influencia de la realidad cotidiana en la elaboración de la normatividad destinada a regir los comportamientos de las mujeres dentro de los monasterios limeños, y principalmente en los actores involucrados en este proceso, atendiendo no solo a las autoridades civiles y eclesiásticas, sino poniendo el foco en el rol desarrollado por las propias profesas y el resto de moradoras de estos centros. ¿Se limitaron a acatar las reglas y disposiciones o, más bien, tuvieron un papel activo en la adaptación y construcción de la normatividad desde el área local?

Son varios los autores que coinciden al señalar que si bien la historiografía ha dedicado una atención considerable a la Iglesia y sus instituciones, ${ }^{3}$ no se ha enfocado lo suficiente en cuestiones del campo del derecho, particularmente en las relativas a los aportes de la normatividad eclesiástica en la conformación del denominado derecho indiano. ${ }^{4} \mathrm{Y}$ si la carencia de trabajos para estos aspectos es notable, los estudios relativos a las mujeres en la construcción de este proceso son casi inexistentes. De este modo, carecemos de una noción clara del rol desempeñado por las religiosas, y otras mujeres, que vivían dentro de los monasterios.

2 Relación del conde de Superunda, Lima, 15 de junio de 1756. En Campos 2011, 1234-1235 y Laserna 1995, 269. Abreviaturas utilizadas: $A A L=$ archivo arzobispal de Lima; $A H M C L=a r c h i v o$ privado del monasterio de la Concepción de Lima; UARM= Universidad Antonio Ruiz de Montoya. Colección del padre Vargas Ugarte.

3 Entre los numerosos estudios sobre la Iglesia en Hispanoamérica y, particularmente, el virreinato peruano podemos señalar: Egaña 1966; Borges 1992; Mayer y Puente Brunke 2015; Lynch 2012; Traslosheros y Zaballa Beascoechea 2010; Armas Medina 1953; Vargas Ugarte 1953-1962; Armas Asín 1999; Estenssoro Fuchs 2003; Acosta 2014 Sobre derecho canónico: Zaballa Beascoechea 2012; Traslosheros 2016 y Duve 2012.

4 Danwerth, Albani y Duve 2019, 1.
El presente estudio se realizará principalmente a partir de la visita realizada a los monasterios grandes limeños, más concretamente al de la Concepción, por el arzobispo Pedro Antonio Barroeta y Ángel en $1754 .{ }^{5}$ Asimismo, las misivas particulares y otras fuentes de documentación serán de gran ayuda a la hora de desentrañar algunos de los interrogantes planteados. Esperamos que el enfoque interdisciplinar del presente trabajo, que combina la historia de las instituciones eclesiásticas con historia de las mujeres desde una perspectiva de género, nos permita obtener un retrato más vívido de las ricas y complejas dinámicas de estas «ciudades celestiales".

\section{Para ordenar lo temporal y lo espiritual: Visitas, autos y otras herramientas}

La mañana del 27 de enero de 1754, una notificación enviada a la abadesa del monasterio de la Concepción de la Ciudad de los Reyes, Rafaela del Molino, informaba de la intención del arzobispo de Lima, don Pedro Antonio de Barroeta y Ángel, de realizar en los próximos meses una inspección en el marco de la visita general de monasterios que llevaría a cabo. La notificación contenía una serie de indicaciones y recomendaciones con el objetivo de que la abadesa pudiese ir cumpliendo con lo solicitado y la visita resultase más rápida y menos molesta para las habitantes del monasterio. Barroeta solicitaba un inventario de las fincas, rentas y demás bienes del convento. Asimismo, pedía: una lista de las obras pías, con su renta correspondiente; otra lista de las capellanías fundadas en la iglesia, señalando sus cargas, capellanes y patronos; y una lista de las cofradías o hermandades que indicara su vocación, cargas y composición. También requería un libro propio para el inventario de las alhajas de la iglesia, altares, santuarios, dormitorios y otros espacios de la comunidad, tales como el refectorio, la enfermería o la cocina. Por último solicitaba otro libro, debidamente indexado, para inventariar los papeles pertenecientes al convento.

No solo las rentas, bienes y finanzas del monasterio eran objeto de escrutinio, sino también la población. El arzobispo solicitaba a la abadesa una lista de todas las religiosas de velo negro, profesas y novicias junto con sus nombres, edades y tiempos de profesión. En dicha lista debían consignarse las criadas que tenía cada una junto con sus nombres, edades y castas. Finalmente, se debía informar tanto sobre los oficios que se repartían entre las religiosas como de sus costos, así como de los gastos realizados por las novicias en la entrada, la toma de hábito y en la profesión. El arzobispo señalaba que «siendo los dichos puntos dignos de la mayor atención y muy oportunos a conseguir en lo temporal», encargaba a la reverenda madre abadesa su cumplimiento «para pasar luego a atender y ordenar lo perteneciente a lo espiritual». 6

Dicha visita se encuentra en el AAL. Monasterio de la Concepción, 33:37, 26 de octubre de 1754, Lima, y en el AHMCL. Autos de visita del monasterio de la Concepción por el arzobispo Pedro Antonio de Barroeta y Ángel. Para la elaboración del presente artículo se han consultado ambas copias, estando incompleta la del AHMCL. Para la historia del Monasterio ver: Vargas Ugarte 1960 y Pérez Miguel 2019.

6 AAL. Monasterio de la Concepción, 33:37, 1754. La visita se daba en una doble vertiente abarcando tanto el aspecto material (Visi- 
Gran desazón debió de causar esta notificación entre las habitantes del monasterio de la Concepción, tanto por las farragosas demandas del arzobispo como por las molestias y nefastas consecuencias que la misma podía acarrear. Las visitas arzobispales no constituían una novedad para los denominados monasterios grandes como el de la Concepción, Encarnación, Santa Clara, Santa Catalina o la Trinidad. ${ }^{7}$ Las autoridades eclesiásticas las realizaban periódicamente con el objetivo de vigilar y controlar las instituciones tanto masculinas como femeninas y poder atajar cualquier relajación de las reglas, proveyendo, en caso necesario, una serie de disposiciones y recomendaciones de acuerdo con las necesidades de cada institución. ${ }^{8}$ Para sujetar a sus súbditas, los superiores empleaban también otras armas canónicas, como la amenaza de excomunión. Sin embargo, Maximiliano Barrio señala que a pesar de los esfuerzos de autoridades eclesiásticas y civiles por imponer el modelo tridentino, las habitantes de los monasterios encontraban diversas estrategias para poder preservar su entidad personal y relativizar la imposición de la clausura estricta, uno de los principales frentes de conflicto. ${ }^{9}$

En el caso del monasterio de la Concepción tenemos constancia de varias visitas en este periodo, siendo algunas de las más destacadas la de Bartolomé Lobo Guerrero (1621), Hernando Arias de Ugarte (1633 y 1637), Diego Morcillo (1725), Pedro Antonio Barroeta y Ángel (1754) y Antonio de Parada (1785). ${ }^{10}$ A juzgar por la documentación

tatio rerum) como espiritual (Visitatio hominum). La primera se ocupaba del estado del monasterio y sus dependencias, incluyendo aspectos como ornamentos, altares, el archivo, rentas, fundaciones y obras pías, entre otros. La parte espiritual vigilaba el correcto cumplimiento del oficio de las religiosas. Tras la inspección el visitador debía corregir aconsejar o castigar las irregularidades detectadas lo cual se hacía a través de los denominados autos de visita, en los que daba cuenta de todo de manera detallada.

Esta distinción se realizaba en consideración al alto índice de la población de estos centros. Dichos monasterios eran los que presentaban mayor número de inconvenientes e irregularidades, por lo que su control era más necesario que en el caso de otras instituciones como las recoletas. Para control y reforma de monasterios femeninos en otras partes del virreinato peruano, particularmente del Cuzco, ver: Burns 2008, cap. 6 y cap.7.

8 Según el Codex luris Canonici, la visita canónica constituye un instrumento de carácter jurídico y pastoral, que posibilita al superior eclesiástico a ejercer su derecho, así como cumplir con su obligación, de examinar a las personas, instituciones católicas, cosas y lugares sagrados dentro del ámbito de su jurisdicción, con el objetivo de comprobar que se está llevando de manera adecuada el fin al que tiende la actividad pastoral que depende de él. CIC, 199,7, 305, 396: § 1 y $\S 2$, 397: § 1, 436: §1,2. Murillo Velarde 1791. Ver también: Candau Chacón 1998. La visita pastoral fue una parte fundamental de la política administrativa de los territorios americanos de la Monarquía Hispánica ya que permitía evaluar el estado de la Iglesia, fortalecer la figura de los obispos y normar a través de ella. A través del III Concilio Limense (1582-1583), ya se animaba a llevar a cabo dichas visitas (Tercer Concilio Limense 2017).

9 Barrio 2010. En los denominados monasterios grandes, gran parte de las monjas de coro, o monjas de velo negro, eran mujeres gran influencia al pertenecer a algunas de las familias más poderosas del virreinato. Estas religiosas tenían sus propios abogados y procuradores y, en no pocas ocasiones, cuestionaron las disposiciones de sus superiores.

10 Sobre la visita de Antonio de Parada ver: Laserna 1995. El autor realiza un detallado estudio sobre el auto del arzobispo de 1775, así como las dificultades de conseguir su aceptación y cumplimiento por parte de las religiosas, particularmente en los monasterios grandes de la Encarnación y la Concepción, siendo su sucesor, González de la Reguera, el encargado de dicha labor. consultada, parece que desde su fundación en 1573 y hasta mediados del siglo XVII, el monasterio no presentó conflictos de importancia o, al menos, no ha quedado constancia de estos. ${ }^{11}$ Quizás la limitada población del monasterio, compuesta en su fundación por poco más de una veintena de religiosas más las criadas y las donadas, hizo más sencillo el control o, lo que es más probable, las desavenencias no llegaron a traspasar los muros. Es a partir del segundo tercio del siglo XVII que encontramos diversas visitas y autos, así como múltiples conflictos entre las religiosas y sus superiores, algunos de los cuales finalizaron ante los tribunales.

Pero ¿cuáles eran los principales problemas que asolaban los claustros femeninos, alejándolos de su estado ideal y su primigenia función de servicio a Dios? Para encontrar la raíz de algunos, debemos remontarnos a la génesis misma de los monasterios virreinales peruanos. María Isabel Viforcos indica que, si bien no faltaron razones de índole espiritual que animaron a multitud de mujeres a entregar su vida al servicio de Dios, las condiciones del territorio durante su conquista y población condicionaron en gran medida su capacidad de elección. ${ }^{12}$ Varias jóvenes decidieron entrar en religión ante la dificultad para contraer matrimonio, ya fuera por su incapacidad de aportar la dote necesaria o por encontrarse en una situación de desamparo. ${ }^{13}$ Este problema perviviría a lo largo de los siglos, ya que los monasterios pronto estuvieron poblados por un gran número de mujeres pertenecientes a la élite, en su mayor parte familiares de conquistadores y encomenderos que al convertirse en profesas de velo negro querían seguir disfrutando de las comodidades de las que habían gozado en sus casas familiares, lo que incluía numerosas criadas y objetos de lujo, queja frecuente por parte de las autoridades, y objeto de censura en las visitas. Si bien muchas podían considerar una vida alejada del siglo, no estaban tan dispuestas a observar las estrictas reglas relacionadas con la clausura, el silencio y la pobreza que exigían las órdenes. Quizás por ello la normativa señalaba que las novicias serían informadas de las cosas que tendrían que respetar como profesas, pudiendo probar un tiempo esa vida para que después no se quejasen de «la aspereça y dificultades que en este divino camino algunas veçes son halladas». ${ }^{14}$ No era hasta después de un año de prueba que la novicia podía proceder a su profesión. ${ }^{15}$

11 Para el siglo XVI, solo hemos encontrado una visita de la que se derivó un informe con recomendaciones acerca del modo de profesar.

12 Viforcos 1995. En el VI Concilio Provincial de Lima, celebrado en 1772 , uno de los aspectos tratados fue, precisamente, la falta de vocación de muchas profesas. José Potau, provisor y vicario general, señalaba que muchas doncellas ingresaban como consecuencia de matrimonios fallidos o falta de dote para los mismos. Ya en el siglo XVII, una relación anónima señalaba que «muchas [mujeres criollas], como en el convento tienen la comida y el vestido seguro, no se quieren aventurar ni ponerse en peligro para ganar la vida». Laserna 1995, 267-268.

13 En el caso del Monasterio de la Concepción, su fundadora, doña Inés Muñoz, señalaba que uno de los principales motivos de su fundación era: «que en el tengan algún remedio muchas hijas de conquistadores pobres que hay en esta ciudad gran suma dellas e padecen grandes riesgos e necesidades» (Pérez Miguel 2019).

14 AHMCL. Códice con la Regla de la OIC (1621), cap. 1, f. 4r.

15 Sin embargo, esto no se observaba y varias veces los superiores solicitaron disposiciones que las obligasen a profesar si llevaban muchos años de noviciado o que se las expulsase. (AAL. Monasterio de la Concepción, 8: 26, 1642). 
Para Viforcos, otro factor de relajación de las normas en los monasterios fue la iniciativa fundacional por parte de seglares. A pesar de que las fundaciones eran acometidas por mujeres de reconocida virtud, esto no era suficiente para poder dirigir adecuadamente a las profesas en el plano espiritual. ${ }^{16}$ Las autoridades fueron conscientes de dicha carencia, por lo que intentaron compensarla trayendo de otros conventos religiosas con experiencia para que ejerciesen como abadesas durante los primeros años, aunque, al final, las fundadoras se impusieron como superioras en gran parte de las ocasiones. ${ }^{17}$ Por ejemplo, en el caso del monasterio de la Trinidad, en 1595, el arzobispo Toribio de Mogrovejo escribía al pontífice Clemente VIII preocupado por la incapacidad de sus fundadoras, doña Lucrecia de Sansoles y su hija doña Mencía de Vega, para llevar a cabo las labores que su cargo requería. Ambas habían obtenido un breve de Gregorio XIII para "ser abadesa y priora de por vida». Sin embargo, el arzobispo señalaba que «de ello se siguen graves inconvenientes por lo que muchas rehúsan ingresar en él y aun cuando en las visitas practicadas, se ha dispuesto que por un sexenio dejen el cargo las susodichas no lo han hecho". ${ }^{18}$

Otro elemento a considerar, y más desde mediados del siglo XVIII, sería el económico. Debemos retomar la mencionada misiva del virrey conde de Superunda acerca de los monasterios grandes de la capital del virreinato peruano a los que tildaba de "pequeñas repúblicas». El virrey señalaba que las rentas no eran suficientes para mantener estos centros: «cada una busca por si el modo de subsistir, o se mantienen a expensas de sus padres y parientes; esto hace muy difícil la reforma porque la prelada ruega y no manda, y cuando no obedecen disimula, no teniendo que responder cuando le dicen que están buscando con qué comer y vestir ${ }^{19}$ Dichas declaraciones exponen la situación de necesidad que acuciaba a los monasterios limeños en el siglo XVIII, intensificada por el catastrófico terremoto acaecido en 1746 que acentuó, aún más, la falta de disciplina existente en las instituciones religiosas femeninas limeñas. ${ }^{20}$

A mediados del siglo XVIII, estos y otros factores convergían para crear un contexto de ruptura de reglas o de ligera observancia de las mismas, así como de permisividad por parte de las abadesas, lo que requería una determinante actuación por parte de las autoridades. Se hacía necesaria

\section{Ibíd.: 528 .}

17 En el caso del monasterio de la Concepción, durante los primeros años se nombró presidenta a la religiosa Juana de la Concepción, aunque no se le concedió la dignidad de abadesa. A partir de 1575, la madre María de Jesús presidió el monasterio con María de la Cruz, ambas religiosas del Monasterio de la Encarnación. Sin embargo, la fundadora, doña Inés, fue la que asumió el báculo abacial desde 1582 hasta su muerte el 3 de junio de 1594.

18 El Papa ordenó deponerlas por autoridad apostólica y que, en adelante, cada trienio se eligieran estos cargos. AUARM. Colección P. Rubén Vargas Ugarte, 29: 166, 23 de noviembre de 1595. T 29-166.

19 Campos 2011, 1234-1235. Relación del conde de Superunda, Lima, 15 de junio de 1756.

${ }^{20}$ A raíz de dicho terremoto, el monarca emitió en 1749 una cédula en la que se disponía, entre otros, la reparación de los conventos dañados, concentrar a las religiosas de la misma regla en una casa y limitar el número de profesas a las que pudieran mantenerse con las rentas disponibles, prohibiendo nuevas profesiones y estableciendo límites a las personas de servicio (Laserna 1995, 267). Sin embargo, dichas disposiciones fueron mayormente ignoradas. Sobre el terremoto ver: Contreras 2011; Pérez-Mallaína 2001; Seiner 2009 y Walker 2012. una visita para el restablecimiento del orden y el decoro, y el responsable en esta ocasión sería el nuevo arzobispo don Pedro Antonio Barroeta y Ángel.

\section{Pedro Antonio Barroeta y Ángel: Un obispo conflictivo}

Son varios los autores que han analizado con profundidad la corriente reformadora en la monarquía hispánica impulsada por los Borbones desde inicios del siglo XVIII. ${ }^{21}$ Sin embargo, si bien es indudable dicha influencia reformista, la cuestión del control y reforma de las instituciones religiosas en el territorio americano fue un proceso continuo que, como señalamos anteriormente, se remonta a siglos atrás. ${ }^{22}$ Asimismo, concordamos con autores como Alicia Fraschina que sin menospreciar la indudable importancia de la iniciativa monárquica, destacan el activo rol desempeñado por las autoridades eclesiásticas y las propias profesas. ${ }^{23}$ Al respecto de esta cuestión, debemos tener también en consideración la propia idiosincrasia de los responsables de llevar a cabo la reforma. En el caso de la visita realizada en 1754, el conocido celo del arzobispo Barroeta, así como su particular carácter impusieron un sello distintivo a la misma y a las disposiciones dadas a su fin.

Pedro Antonio de Barroeta, nacido en 1701 en Ezcaray (La Rioja), fue propuesto en 1748 por el Papa Benedicto XIV para ser arzobispo de la iglesia metropolitana de Lima, vacante desde $1745 .{ }^{24}$ Su candidatura no fue bien acogida en el virreinato debido a que el entonces virrey, Manso de Velasco, había propuesto ya al oidor Juan Bravo de Ribero, natural de Lima, quien contaba con experiencia previa en el territorio americano como regidor del obispado de Arequipa y de Santiago de Chile, y como oidor en la Real Audiencia de Charcas. ${ }^{25}$ Sin embargo, la Iglesia de Lima se encontraba bajo el Real Patronato castellano sin mediar, por lo tanto, acceso directo a la Santa Sede. Por este motivo, la elección del arzobispo quedaba reservada al monarca, quien se decantó por Barroeta. ${ }^{26}$ Tras su nombramiento, el nuevo arzobispo

21 Sobre reformas borbónicas ver: O’Phelan 1995a, 1995b, 2015 y 1988; Moreno Cebrián 1983, 2000 y 2003; Lynch 1996 y 2012; Latasa 2003.

22 Sobre regulaciones trentinas y concilios y sínodos limenses, y su aplicación en los monasterios femeninos ver: Viforcos 1995 y 2005. Para los concilios: Vargas Ugarte 1951-1954 y Tercer Concilio Limense 2017.

23 Alicia Fraschina analiza las reformas en los conventos femeninos de varias partes de Hispanoamérica desde 1750 hasta 1865 , observando, principalmente, las tensiones y contradicciones fruto de estas. La autora señala como la insistencia de la historiografía en el protagonismo de la Corona en las reformas ha opacado los emprendimientos llevados a cabo por otros actores. Así, señala que otra corriente historiográfica, por el contrario «percibe una indudable iniciativa y/o colaboración de prelados y hombres de la jerarquía eclesiástica, así como de las propias monjas» (Fraschina 2008, 446-447). Estudios pertenecientes a esta última corriente serían los de Lavrin 1965, 2006; y Chowning 2005.

24 Bula firmada en Roma el 25 de septiembre de 1748.

25 Existían otros candidatos cercanos al círculo del virrey como el mercedario Francisco Gutiérrez Galeano, auxiliar del obispado de Lima.

26 Martínez Martín 2008, 150. Varios autores coinciden al señalar que la razón de su elección estaría relacionada con el clientelismo del arzobispo con el marqués de la Ensenada, natural de Ojacastro, población cercana a Ezcaray, y personaje clave en la vida política durante el reinado de Fernando VI. 
viajó con varios allegados y familiares, y llegó a Lima el 28 de junio de $1751 .{ }^{27}$

\section{IMAGEN 1}

Retrato del arzobispo Pedro Antonio de Barroeta y Ángel

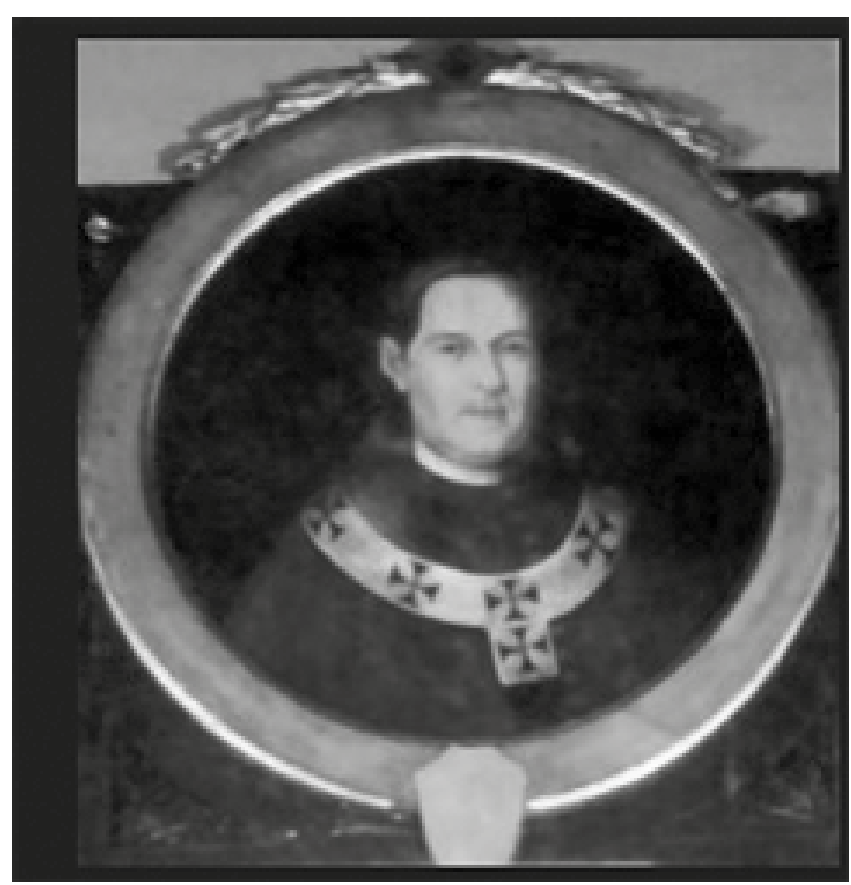

Fuente: Domingo de Vivero 1892, 25.

Se ha vertido abundante tinta acerca de esta controvertida figura. El historiador J. M. Lavalle destaca su inclinación a mandar de forma despótica, a lo que añade su falta de experiencia para el cargo designado..28 También Carmen Martínez señala que Barroeta era conocido por su severa disciplina y genio intransigente, "siempre con la Recopilación de las Leyes de Indias en la mano para defensa contra el abuso del Patronato Real». ${ }^{29}$ Del mismo modo, el padre Vargas Ugarte poner de relieve "su falta de tacto y mesura y su obsesión por insistir en asuntos de poca importancia relativos al ritual, sosteniendo su postura con demasiado vigor». Según el autor, siendo ya ardua la labor de Barroeta, su intransigencia la complicó aún más, lo que le provocó la animadversión de un gran número de personas e instituciones, incluido el mismísimo virrey conde de Superunda. ${ }^{30}$ De hecho, las fuertes tensio-

27 Sobre Barroeta ver: Martínez Martín 2008; Vargas Ugarte 1961; Pérez-Mallaína 2001; Mendiburu 1876, 2: 391; Moreno Cebrián 1983 y 2003 y Carrillo 2018.

28 Martínez Martín 2008.

29 Además, Barroeta no dudaba en acudir tanto a la normativa trentina como a las bulas papales para respaldar sus actuaciones. Ibíd.: 148.

30 Emilio Pérez-Mallaína señala que, más allá de disputas protocolares, el motivo de animosidad entre el arzobispo, el cabildo catedralicio y varias órdenes religiosas, serían cuestiones como los salarios, capellanías, patronatos o rentas (Pérez-Mallaína 2001). Quizás, el incidente más conocido entre el arzobispo con el virrey fue el relativo a un quitasol que el conde de Superunda prohibió usar al prelado durante una procesión por ser privilegio exclusivo de los virreyes (Vargas Ugarte 1961, 128; Moreno Cebrián 2003, 171; Martínez Martín 2008, 156). En su descargo el virrey señalaba que solo estaba permitido su uso a los virreyes en actos oficiales porque "sería una indecencia que se interpusiese un lacayo negro, o mulato, que son los que se destinan nes del arzobispo con el virrey, el cabildo y otros organismos ocasionaron que, a tan solo siete años de su llegada al Perú, Carlos III lo promoviese a la sede vacante de Granada, sucediéndole en el cargo su secretario Diego del Corro.

Durante el breve periodo de su prelacía, Barroeta desarrolló una gran actividad pastoral, testimonio de la cual es un gran acervo documental compuesto por numerosos edictos, dos cartas pastorales, una nueva edición de la $R e$ copilación de leyes de Indias, prologada por él mismo, y la publicación de diversos estatutos eclesiásticos y sinodales hechos por sus antecesores. Mendiburu señala que «ningún arzobispo expidió más edictos que Barroeta para reprimir abusos y sostener el decoro". ${ }^{31}$ Vargas Ugarte coincide al señalar que «dio pruebas manifiestas de su celo y solicitud pastoral», tratando de restaurar la disciplina eclesiástica, vulnerada en gran parte por la dejadez y falta de espíritu de miembros del clero. ${ }^{32}$ Este celo en el cumplimiento de las normas y en el respeto del decoro se refleja en la minuciosidad con la que llevó a cabo su visita, así como en las detalladas constituciones dadas por él tras la misma, tal y como veremos a continuación.

\section{"Y se reformen las cosas que sean dignas de remedio": la visita general al monasterio de la Concepción (1754)}

Una de las más importantes y espinosas misiones del arzobispo fue evaluar el estado de su Iglesia, contexto en el que propuso una visita general de monasterios femeninos que comenzó a finales de 1754 en el monasterio de la Concepción de Lima. El 17 de octubre, habiendo pasado más de ocho meses desde el aviso de la misma, Barroeta señalaba que se hacía preciso dar inicio, entre otros motivos, por hallarse la abadesa Rafaela del Molino en los últimos meses de su prelacía. ${ }^{33}$ Para llevar a cabo su propósito, Barroeta nombró como acompañantes al chantre don Fernando de Sota, el canónigo teologal Fernando Cavero y don Joseph Barbadillo, abogado de los reales consejos y cura rector de la parroquia de Santa Ana, quien se desempeñaría como notario y secretario en la visita. ${ }^{34}$

El 20 de octubre, a las 7.30 de la mañana, el arzobispo llegaba a la puerta del monasterio con sus acompañantes para ser recibidos por: el capellán, Mariano Bermúdez; el maestro de ceremonias, don Francisco de Armas y Rotalde; un diácono; un subdiácono, y dos portadores de un palio que llevaron al prelado hasta el interior del templo. A la en-

a estos servicios, dando la espalda al virrey y a la audiencia». Barroeta defendía su derecho indicando que el lacayo no iba en medio, sino en un lateral, y, además, el uso de ese objeto no era una prerrogativa honorífica, sino algo necesario para protegerse del sol (Carrillo 2018, 4-5).

31 Mendiburu 1876, 2: 391. Según Vargas Ugarte, el prelado argumentaba que prefería acudir a los edictos que convocar un Sínodo, el cuál obligaba a los párrocos a dejar sus curatos y a movilizarse con gran dificultad, debido a la distancia y falta de vías de comunicación (Vargas Ugarte 1961, 190).

32 Vargas Ugarte 1961.

33 Su gobierno finalizaba el 22 de diciembre.

34 José Barbadillo y Frías, hijo de Francisco y María Frías de Anguiano, era natural de Ezcaray, al igual que Barroeta, y formó parte del grupo con el que viajó el arzobispo al territorio peruano. Llegó como presbítero, abogado de los Reales Consejos, siendo pronto nombrado cura rector de la parroquia de Santa Ana, donde permaneció cuando Barroeta regresó a la Península. 
trada de la capilla principal se había colocado una alfombra y un cojín en el que el arzobispo se hincó de rodillas para adorar la cruz. Acto seguido, roció con agua bendita a los circunstantes y preparó el incensario, que fue movido, exactamente, tres veces por el capellán. Las religiosas entonaron el Te Deum laudamus, mientras Barroeta pasaba por debajo del palio al altar mayor. ${ }^{35}$ Una vez allí, el arzobispo dio la bendición y se dirigió a continuación junto a la rejilla del coro, donde lo esperaban las profesas. Tras sentarse en una silla, debajo de un dosel que le habían preparado, Barroeta hizo público el motivo de su visita y ordenó publicar una copia del edicto en el coro del convento para que ninguna monja pudiera aducir desconocimiento. Tras su anuncio volvió al altar mayor, donde llevó a cabo una misa sagrada y, al acabar, comenzó una procesión mientras se cantaban los responsos y oraciones acostumbrados en las visitas.

Una vez concluida la procesión, Barroeta procedió a examinar el altar mayor y la hostia consagrada. Pasó a continuación al altar del Santísimo Cristo, ubicado en la reja del coro, donde inspeccionó el tabernáculo y los copones, para finalizar en un tercer altar donde se conservaba el santo óleo para los enfermos. Barbadillo, fiel notario, señalaba que el obispo "halló todo con bastante decencia». ${ }^{36}$ Tras terminar la inspección de la iglesia, el arzobispo entró a la clausura, donde visitó la sacristía interior, la capilla del santuario, el espacio donde las donadas tenían sus distribuciones espirituales, la capilla del Carmen y la sala interior del locutorio. Al concluir su inspección, Barroeta volvió al coro, donde todas las religiosas le esperaban, y mantuvo con ellas «una breve y saludable plática sobre la utilidad espiritual de la visita» y lo que las religiosas debían hacer «para que se reformasen las cosas que fueran dignas de remedio». Tras esto salió de la iglesia junto con todos sus acompañantes.

Dada la enorme extensión y población del monasterio de la Concepción, uno de los más grandes de la Ciudad de los Reyes, serían necesarias varias jornadas para poder realizar la visita. El día 26 de octubre, a las 9.00 de la mañana, el arzobispo y su comitiva, a la que se sumaron los jesuitas Luis Rodríguez y Joseph Meléndez, se presentaban en el templo para proseguir con su cometido. Una vez dentro, Barroeta ordenó a las religiosas retirarse a sus alojamientos, permitiendo que le acompañaran en su reconocimiento únicamente algunas profesas, entre las que se encontraba la abadesa. ${ }^{37}$

El propósito de esta jornada era la supervisión del correcto cumplimiento de la clausura. Para ello, el prelado visitó el torno de la sacristía, las rejillas de los confesionarios, el comulgatorio, la clausura del convento y las puertas de la reja del coro. Del mismo modo, examinó las dos puertas de la clausura del monasterio - principal y falsa-, los locutorios, los tornos, los dormitorios y los archivos, hallando todo en buena disposición. Finalmente, visitó las cercas y subió a algunos tejados de las celdas para observar tanto la dificultad de subida a los mismos como la vista que se tenía desde ellos. En esta ocasión sí «halló algunas cosas dignas de remedio", las cuales serían consideradas con posterioridad en el auto correspondiente.

35 AAL: monasterio de la Concepción 33:37, 26 de octubre de 1754, f. $4 r$.

36 Ibíd.

37 Juana Poveda, Magdalena Izquierdo, Sinforosa Cordero, Josefa Obregón, Josefa Laínez, Isabel Muñicio y Francisca Morete.
Tres días más tarde, el 29 de octubre, continuaba la visita, destinada en esta jornada a evaluar el desempeño de la abadesa Rafaela del Molino. Tal y como era usual, la prelada fue suspendida temporalmente del cargo, siendo nombrada como presidenta Rosa Carrillo, a quien se entregaron el báculo, el sello y las llaves de la clausura, distintivos de esta dignidad. Para examinar a la prelada y cuestionar su cumplimiento de las obligaciones, Barroeta dispuso un interrogatorio en la puertecilla del comulgatorio a las doce monjas «más antiguas y de mayor graduación y virtud». ${ }^{38}$ Asimismo, se hicieron averiguaciones sobre el desempeño de la vicaria, las porteras y el capellán por ser estos los puestos más importantes y que mayor celo y responsabilidad demandaban en su cumplimiento. Tras tomar nota de los comentarios de las religiosas, Barroeta consideró que no había acusaciones graves, por lo que tras una «paternal reprehensión» restituyó a Rafaela del Molino su cargo y le devolvió sus insignias. ${ }^{39}$

\section{IMAGEN 2 \\ Retrato de la abadesa Rafaela del Molino y Barañán}

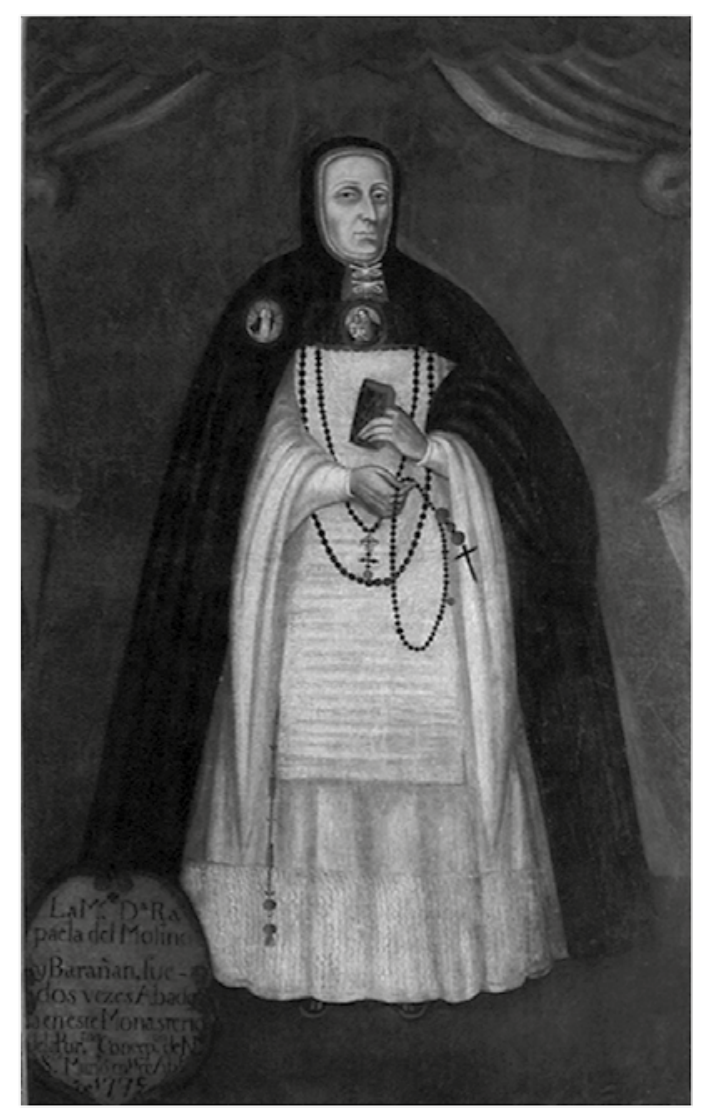

Fuente: AHMCL. Anónimo. S. XVIII. Retrato de doña Rafaela del Molino y Barañán, dos veces abadesa en este monasterio de la Purísima Concepción de Nuestra Señora, murió en este año de 1775.

38 Bárbara Luján, Juana Poveda, Sinforosa Cordero, Josefa Obregón, Isabel Muñicio, Josefa Laínez, Magdalena Izquierdo, Isabel María Ortega, Francisca Carrillo, Agustina Puente, Magdalena del Sacramento, y María de la Oliva.

39 El detallado ritual realizado por Barroeta sería repetido, de manera casi idéntica, en la visita al Monasterio de la Santísima Trinidad de San Bernardo, y creemos, aunque no hay pruebas documentales de ello, en el resto de monasterios. Al igual que en la Concepción, inspeccionó la iglesia, la clausura e inquirió acerca del desempeño de la abadesa, aunque en esta ocasión no hubo objeciones y la felicitó por su desempeño. AAL. Monasterio de la Trinidad, 12: 6, 1754. 
Al día siguiente, el arzobispo continuó con sus averiguaciones, esta vez acerca del cumplimiento de obligaciones y observancia de votos por parte de las profesas. En esta ocasión convocó a seis religiosas: las hermanas Catalina y Juana Poveda, Sinforosa Cordero, Silveria del Castillo, Magdalena del Sacramento y Magdalena Izquierdo, todas las cuales informaron al arzobispo sobre los asuntos que, a su parecer, debían ser remediados. El 31 de octubre, último día de la visita, el arzobispo continuó con su inquisición, siendo en esta jornada siete las monjas interrogadas. ${ }^{40}$

Los comentarios de las religiosas en los interrogatorios del 30 y 31 de octubre fueron recogidos cuidadosamente por el secretario y notario de la visita, Joseph Barbadillo. ${ }^{41}$ Dicho documento, presenta un total de trece epígrafes que, consideramos, corresponderían a cada una de las profesas examinadas: seis el día 30 y siete el $31 .^{42}$ Dado que no consta el nombre de las informantes ni sabemos en qué orden fueron convocadas, desconocemos a quién corresponde cada una de las observaciones. Sin embargo, llama la atención la denuncia común de varios aspectos, tales como problemas con la vestimenta, la falta de observancia de los votos y obligaciones del coro, así como la desobediencia de las criadas, temas en los que profundizaremos a continuación.

\section{Construyendo la normatividad}

El 9 de noviembre de 1754, poco después de concluir la visita, el arzobispo emitía un auto destinado a corregir y regular varios temas relativos al templo y a sus internas. Deseamos destacar que la mayor parte de dicho auto estaba conformado por las observaciones, solicitudes y sugerencias hechas por las religiosas durante el interrogatorio privado, las cuales se habían transformado en disposiciones.

Una de las cuestiones más denunciadas durante las entrevistas con el arzobispo había sido las vestimentas de las seglares, a quienes se acusaba de usar faldellines de seda "y ropas y ligas de seda encarnadas». Asimismo, se señalaba que su vestido era "muy profano y alto», lo que permitía ver sus zapatos, algo prohibido por varias disposiciones y edictos. ${ }^{43}$ Las religiosas también expresaban su disgusto por el uso de tupés, perlas y diamantes tanto por seglares como por donadas, criadas y esclavas. ${ }^{44}$ Pero no solo estas hacían semejantes alardes, ya que algunas religiosas también eran acusadas de usar medias de seda, ropas de Cambray, sorti-

40 Las religiosas interrogadas fueron Francisca Carrillo, Josepha Casanova, Ana Terán, Francisca Morete, Micaela Garcés, maestra de donadas, Rosa Carrillo y Agustina Puente.

41 AAL. Monasterio de la Concepción, 33: 38, 1754. Borrador con observaciones para la reforma del monasterio de la Concepción.

42 Los epígrafes, 12 y 13, no llegaron a ser desarrollados. Quizás las religiosas no dieron información de importancia o no fue recogida por el notario.

43 Se exigía que la falda, o saya femenina, cubriera los zapatos, con el fin de eliminar la visión de los pies, posible punto de seducción. Scarlett O'Phelan, señala cómo hasta el siglo XVIII, las damas españolas, y por ende las criollas, tenía vedado el enseñar los pies a miembros del sexo opuesto (O'Phelan 2007, 24-25).

44 Tal y como señala O'Phelan, las criadas y esclavas eran consideradas una extensión de la familia a la que pertenecían. Por este motivo, una familia que se preciara de alcurnia ponía especial cuidado en que vistieran bien, pudiendo incluso acicalarlas con joyas ( $O^{\prime} P h e l a n$ 2003, 103). jas y «cintas de mucho precio y labores de bordados en los escapularios», y de llevar sus hábitos muy altos e, incluso, de no llevarlos en alguna ocasión. ${ }^{45}$

Todas estas cuestiones eran reguladas en el nuevo auto arzobispal a través de las disposiciones $17,35,36$ y 43, las cuales mandaban observar el alto reglamentario de la ropa y llevar siempre el hábito, reformaban el adorno en los zapatos y prohibían el uso de medias y ligas de seda, las cuales debían ser cambiadas por otras de algodón. ${ }^{46}$ Del mismo modo se censuraba el uso de telas preciosas de lino, de Cambray o de clarín, y obligaba a vestir "de Bretaña o Ruan, ${ }^{47} \sin$ tener en sus celdas alhajas de plata, oro, pedrerías, menaje precioso y otros adornos que solo convienen a la gente del siglo». ${ }^{48}$ Respecto a las seglares, se les ordenaba vestir de lana y se les prohibía usar "faldellines u otras ropas de seda, procurando traer siempre cubiertos los brazos y pechos con sus manguitos de lienzo y la ropa larga hasta el talón del zapato, como les es mandado por edictos publicados a este fin», amenazando con su expulsión si no lo cumplían. ${ }^{49}$

Otro punto común en las denuncias de las religiosas durante la visita había sido el escandaloso comportamiento de las criadas y su falta de respeto hacia las religiosas, problema que veremos a continuación con mayor detalle. Las disposiciones 13, 19, 27, 37, 39 y 44 atendían a este asunto estableciendo, entre otros, que cada religiosa no pudiese tener más de dos criadas y que ambas fuesen mayores de veinte años. ${ }^{50}$

También se regulaban varios aspectos relativos a las seglares. Por ejemplo, durante el interrogatorio, una de las profesas había sugerido que estas pagasen «por el piso 50 pesos cada año" y que no se admitiesen nuevas internas "sin que afiancen a satisfacción de la madre abadesa». Observamos que el arzobispo atendió esta propuesta, ya que en la disposición número 46 se disponía dicho pago y la aprobación de la prelada. Del mismo modo, varias religiosas habían denunciado el comportamiento poco adecuado de algunas de estas mujeres, como Francisca Zegarra, quien habría mantenido relaciones ilícitas con otras seglares. También eran acusadas por el mismo motivo Teresa Lucía,

45 AAL. Monasterio de la Concepción, 33: 37, 1754.

46 Ibíd.

47 La bretaña era un lienzo fino procedente de Bretaña en Francia, al igual que el ruan que se manufacturaban en la ciudad del mismo nombre y se empleaban en confeccionar tocas y vueltas de puño, haciéndose lo propio con el Cambray lienzo muy delgado procedente de la ciudad de Cambray (O'Phelan 2007, 24-25).

48 Asimismo, se prohibía a las religiosas vestir a las criadas «o a las muchachas de seda, puntas o perlas».

49 Pérez-Mallaína señala que el arzobispo, a través de cartas pastorales o edictos públicos, pretendía corregir los abusos y dar las normas de decoro que debían seguir los habitantes de Lima, disposiciones que muchos consideraban excesivas. En un edicto del 15 de septiembre de 1751, reguló el vestido que debían usar las mujeres, el cual debía cubrir los brazos hasta la muñeca. Asimismo, debían usar sayas o faldellines hasta el tobillo (Pérez-Mallaina 2001, 165). Si esto era así para las mujeres del siglo, con más razón, debía controlarse en los monasterios. O'Phelan indica como el Barroeta llegó a denunciar el poco recato de las mujeres en el vestir como causante del terremoto (O'Phelan 2007, 24).

50 La disposición 37 prohibía a las religiosas tener más de dos criadas. Estas debían ser mayores de 20 años, y solo aquellas de más de 30 podrían salir a hacer recados. Por su parte la disposición 39 reiteraba esta orden "con particular encargó» a la abadesa solicitando asimismo dar cuenta al arzobispo. AAL. Monasterio de la Concepción, 33: 37,1754 . 
Jacoba de León y las donadas Cathalina Moreno y Josepha Vásquez: «por inhonesto recíproco trato». Quizás dichas declaraciones motivasen las disposiciones 41 y 42 , en las que se ordenaba que ninguna seglar saliera sin permiso del arzobispo y que no pudieran vivir en las mismas celdas de las profesas.

Tampoco el cumplimiento de las obligaciones religiosas escapaba de la denuncia de las monjas, quienes se lamentaban de hechos como la falta de asistencia al coro o la entrada de criadas y niñas durante el oficio, lo que suponía una distracción. De hecho, varias profesas se quejaban de la presencia de niños y niñas de todas las castas, los cuales se criaban en el monasterio a pesar de no estar permitido e interferían en el cumplimiento de sus obligaciones. El auto arzobispal a través de las disposiciones 12,28 y 34 se encargaba de regular ambos problemas prohibiendo, entre otros, la presencia de estos menores en el monasterio.

Por último, varias de las religiosas habían expresado su preocupación en relación con las elecciones de abadesa y de profesas, solicitando que el voto fuera secreto y que se moderasen las celebraciones tras las elecciones. Las profesas se quejaban de las corridas de toros que se hacían por motivo de la elección de abadesa, que conllevaban, además de un desorden en la clausura, la entrada de personas de otro sexo sin el permiso correspondiente. Ambos aspectos también eran oportunamente regulados, ordenando las disposiciones 41 y 15, respectivamente, que el voto fuera secreto y que no pudiesen entrar ni reses ni toreros.

Como se puede observar, los datos provistos por las religiosas a través de sus reclamos, sugerencias y peticiones durante el interrogatorio fueron de vital importancia en la elaboración de las disposiciones arzobispales dadas tras la visita. ${ }^{51}$ No obstante, debemos señalar que esta no era la única fuente de información para Barroeta, ya que algunas profesas también le habían asesorado acerca de lo que debía ser remediado a través de correspondencia secreta antes, durante y tras la visita.

\section{"Pues mal podrá remediar lo que no se sabe...»}

Las afirmaciones de diversos autores sobre el proceso de relajación moral sufrido en la ciudad de Lima a lo largo del siglo XVIII, del que no habrían escapado los monasterios, ${ }^{52}$ parecen ser ratificadas por las incendiarias declaraciones de las monjas de velo negro Magdalena del Sacramento y Sinforosa Cordero en varias misivas enviadas al arzobispo. En

51 Barroeta también reguló algunos aspectos que había observado en persona durante su visita, como la subida a los tejados y la exposición de algunas celdas que ponían en peligro la clausura: «16. La celda de Petronila Castillo esta frente a la puerta y asisten con frecuencia religiosas donadas y seglares vestidas con adornos para ver y ser vistas por los que pasan por la calle manda que ya no se pueda y que lo vigile la abadesa» y «22. Que se quiten y derriben las subidas que ay a los terrados por las celdas de doña Nicolasa Aramburu, doña Theresa de los Santos y de doña Gabriela del Castillo [...] no se use escalera levadiza para subir e otras celdas que sabe el arzobispo». Del mismo modo, reiteró el deber de cumplimiento de la regla, con especial atención a la clausura y a la observancia de aspectos espirituales. AAL. Monasterio de la Concepción, 33: 37, 1754. Este aspecto de la clausura fue de particular importancia en los monasterios femeninos de la capital y el causante de numerosos problemas relativos a su incumplimiento (Pérez Miguel 2019 y Serrera 2009).

52 Juan y Ulloa 1991; Pérez-Mallaína 2001; Laserna 1995. ellas, ambas religiosas realizaban una apasionada defensa de la necesidad de una visita para remediar los males que asolaban al monasterio de la Concepción. El 28 de agosto de 1754, doña Magdalena del Sacramento, tras tener noticia de la visita general, escribía al prelado solicitándole comenzar por la Concepción, donde la «calamidad es mayor y más lamentable la penuria». ${ }^{53}$ La profesa indicaba que al ser varias las religiosas «de virtud sólida y ejemplar vida» que deseaban una reforma para vivir de manera adecuada en religión, no dudarían en contar los abusos que se manifestaban en la clausura para que el arzobispo pudiera remediarlos. En su misiva narraba cómo, durante varios años, ella y otras habían soportado muchos inconvenientes y, aunque habían pedido ayuda a sus superiores, únicamente habían obtenido una exhortación pastoral al provisor. Así, la profesa no dudaba en manifestar su alegría por la visita: «Vuestra Ilustrísima tiene convocados a sus monasterios para que oigan su doctrina por medio de una visita que deseo lo que tan grande proeza siguiendo el norte de la prudencia y discreción que en los socorros y necesidades sabe guardar». ${ }^{54}$

A fines de octubre, ya iniciada la misma, Magdalena escribía una segunda carta al prelado en la que exponía su preocupación por que no llegara a realizar las reformas necesarias. La religiosa se justificaba señalando que durante los interrogatorios, aunque el arzobispo había mandado decir la verdad, gran parte de las profesas habían callado por miedo, ya que la abadesa las había amenazado. Sin embargo, doña Magdalena indicaba: «alumbrándome Dios, conozco y debo decir la verdad $» .{ }^{55}$ De este modo, la religiosa comenzaba sus denuncias con la narración del lamentable estado de los servicios del monasterio, en particular la enfermería. Sin embargo, el asunto de mayor gravedad, y que en su opinión ameritaba mayor urgencia en su reparo, era el de las criadas, a quienes dedicaba duras acusaciones:

Ellas son la perdición de esta casa. No puede haber silencio si las religiosas están en oración [...] ni se les puede hablar, porque si les reprenden algo malo las ponen como un suelo a desvergüenzas, que esto es para llorarlo, y todos los días vivimos clamando a Dios. Ellas viven en esta casa como Sodoma, todas en malas amistades y unas con otras dando escándalo. ${ }^{56}$

Magdalena se quejaba de que las criadas tenían gallinas, patos y pollos, los cuales ensuciaban todo el convento y se metían en las celdas. Doña Magdalena lamentaba que, si bien durante las visitas la abadesa y vicaria mandaban limpiar todo y esconder a los animales, estos eran liberados una vez concluían. ${ }^{57}$ También las vestimentas de las criadas eran objeto de su denuncia, pues la religiosa aseguraba que estaban «profanamente vestidas [...] Ilenas de clarines, sarcillos, cintas de telas, las ropas a media pierna, las ligas colgando que una mujer del mundo no estuviera más escanda-

53 AAL. Monasterio de la Concepción, 33: 36, 28 de agosto de 1754. Carta de sor Magdalena del Sacramento al arzobispo de Lima.

54 Ibíd. f. 1.

55 Ibíd., 33: 33, 1754. Carta de Sor Magdalena de la Concepción al arzobispo de Lima.

56 Ibíd.

57 Esta queja también había sido formulada durante el interrogatorio, seguramente por la propia Magdalena, y fue atendida por el arzobispo quien a través de la disposición 14 prohibía la presencia de animales como gallinas, patos o perros dentro del Monasterio. 
losa». A pesar de los antes mencionados edictos en contra del uso de las sayas de seda y faldellines, algunos dictados por el propio Barroeta, las criadas los vestían burlándose de las disposiciones. ${ }^{58}$ Por si fuera poco, las criadas también poseían celdas y esclavas y, además, Magdalena las acusaba de no respetar la clausura - ya que subían a las cercas y tenían correspondencia con gente del exterior - y de robar en el monasterio para engalanarse, lamentándose de que ni los candeleros de las imágenes estaban seguros en el coro. Sor Magdalena señalaba que «solo para hablar del desorden de las criadas es menester resmas de papel», y denunciaba, con gran amargura, los hechos:

Son las criadas nuestra destrucción [...] están alzadas con la casa y son dueñas de ella, las músicas que hacen por el convento cantando cantares lascivos y trayendo a los oídos de las religiosas todas las palabras y desenvolturas del siglo, que ni aun en su celda esta una monja segura de oír lo que no quisiera, esto es digno de llorarlo con lágrimas de sangre. ${ }^{59}$

Sin embargo, la monja se lamentaba al arzobispo de que, si todo esto llegaba a oídos de la prelada, esta solo las regañaba ligeramente, por lo que las criadas no moderaban su comportamiento: «esto está perdido, es la casa de Babilonia no puede haber ni paz ni silencio, si una criada avergüenza a una religiosa la misma ama suya la defiende y no le hace nada la abadesa». Según Magdalena, el motivo de permitir estos desmanes sería, además del miedo de las profesas, la vergüenza de verse "ultrajadas de una inferior», por lo que "callan y sufren un infierno". Asimismo, dado que las criadas formaban parte de los bandos electorales y eran tan numerosas, las preladas no querían enfrentarse a ellas «por no perder los bitores y ruidos que en el convento hacen para festejarlas». Continuando con el tema de las elecciones, Magdalena indicaba que el ingreso de una religiosa se votaba con frijoles blancos y negros a la vista de todo el coro, lo que ocasionaba que muchas votaran por profesas poco recomendables para no ganarse la enemistad del resto. Lo mismo sucedía con la elección de la abadesa, motivo por el cual pedía al arzobispo ordenar «que cada una haga su voto como su conciencia le pareciera y este sea oculto». ${ }^{60}$

Para finalizar, la religiosa señalaba en un tono bastante apocalíptico que las que vivían de acuerdo a sus votos eran, desafortunadamente, una minoría, y que el resto no constituían más que una carga y una ofensa: «no sé cómo Dios no hunde esta casa y la confunde, pues son muy raras las que viven bien». La religiosa indicaba narrar únicamente: «una parte de lo que hay en el convento que remediar, pues creo que era menester que Jesucristo bajara del cielo a componer esta casa». Por este motivo solicitaba al arzobispo llevar a cabo una necesaria reforma, y le daba para ello una se-

58 Según señalaba la religiosa, las donadas estaban tan relajadas como las criadas y solo se distinguían de las seglares cuando se ponían el hábito. Magdalena se lamentaba de que ni siquiera respetaban el cumplimiento del oficio divino y entraban al coro sin saya.

59 Ibíd.

60 Probablemente, esta denuncia que fue manifestada durante el interrogatorio privado corresponda a Magdalena. Tal y como señalamos anteriormente, la solicitud se materializó en la disposición número 41 que ordenaba que el voto fuera secreto "por los graves inconvenientes que se resultan de que se hagan en otra forma». AAL. Monasterio de la Concepción, 33: 37, 1754. rie de recomendaciones muy concretas, aduciendo que lo hacía por ser «preciso darle parte de estas cosas, pues mal podrá remediar lo que no se sabe». Así, Magdalena solicitaba prohibir los gallineros y animales dentro del monasterio, y castigar el libertinaje de las criadas, insinuando, incluso, que fueran expulsadas: "fuera más licito que estuvieren en el siglo y no viviendo aquí todas mal amistadas dándonos tantos escándalos con sus desenvolturas». ${ }^{61}$ La religiosa aprovechaba las últimas líneas de su misiva para indicar que seguiría informando sobre asuntos dignos de la atención del prelado y para cargar la reforma sobre la conciencia del arzobispo: «si su llustrísima sabiéndolas [verdades] no las remediare allá se entenderá con Dios».

Pero sor Magdalena no era la única religiosa que mantenía correspondencia con el prelado. También Sinforosa Cordero y Espinosa, monja de velo negro, le escribía para exponer de manera muy pormenorizada varios asuntos dignos de censura, incluso referidos a las cuentas del monasterio, sustentando sus acusaciones con diversas pruebas materiales. La primera misiva que conservamos de Sinforosa a Barroeta corresponde al 1 de noviembre, tan solo un día después de finalizar la visita. Probablemente, durante la entrevista privada con el arzobispo, este le habría indicado que si quería añadir algo a lo declarado, podría hacerlo mediante esta vía. O quizás la propia profesa había tomado la iniciativa para mostrarse como una buena religiosa, confiable y sujeta a su autoridad. ${ }^{62}$

Sinforosa comenzaba su primera misiva aludiendo a su carácter privado y a su propósito: «Esta solo Vuestra Ilustrísima las ha de leer, y todo lo que va en ellas prometo sea todo como en la presencia de Dios al fin se ataje este cáncer». A continuación, relataba una serie de irregularidades cometidas tanto por la actual abadesa como por la anterior y el mayordomo, las cuales habrían causado una gran ruina al monasterio y a sus internas en tiempos tan difíciles y de tanta necesidad como el reciente terremoto de $1746 .{ }^{63}$

Sinforosa escribía de nuevo al día siguiente, esta vez para dar parte «de los buenos efectos que van produciendo de la visita». ${ }^{64}$ La religiosa señalaba que ahora las profesas iban vestidas al coro con sus hábitos de monjas. Asimismo, al igual que Magdalena, aprovechaba para denunciar el comportamiento de las criadas y solicitaba que fueran vestidas como las religiosas, que no hubiera clarines, que no vivieran

61 Ibíd. Recordemos que la solicitud sobre los animales también fue atendida. Cfr. nota 57.

62 Al momento de la visita, el arzobispo había solicitado a las religiosas dar noticia secreta de cualquier asunto por lo que estas misivas no serían algo irregular. Asimismo, en las disposiciones dadas tras la misma, Barroeta ordenaba que si algo de lo dispuesto no se cumplía se le diese aviso en secreto «con apercibimiento de que con la que contraviene en todo o parte se hará una demostración muy ejemplar». AAL. Monasterio de la Concepción, 33: 37, 1754. De este modo, consideramos que el proceder de Sinforosa no se enmarcaría en la excepcionalidad al contrario que otros autores como Ybeth Arias, quien sostiene el carácter inusual de esta actuación que no forma parte de un requisito formal, sino que es una iniciativa personal de la religiosa (Arias 2009, 108). En su estudio la autora analiza la visita de Barroeta en el contexto de las reformas borbónicas.

63 Según Sinforosa, el mayordomo Poveda (hermano de dos religiosas de velo negro) había malversado 12000 pesos de la caja de dotes y otros fondos de las internas, y la actual abadesa habría sabido, y consentido, parte de estas actuaciones. AAL. Monasterio de la Concepción, 33: 39, 1754.

64 AAL. Monasterio de la Concepción, 33: 40, 02-11-1754. 
en las celdas y que disminuyera su número, lo que se podría conseguir si no se daban más licencias. Del mismo modo, sugería que las criadas más jóvenes sustituyesen a las más mayores. ${ }^{65}$ Respecto a las cuentas del monasterio, Sinforosa aconsejaba a Barroeta examinar las rentas durante su visita, pero sin dejarse aconsejar por el capellán, el Sr. Mengoa, "dueño de los tapadijos».

Pocos días después, el 6 de noviembre, Sinforosa hacía llegar al arzobispo una memoria de los gastos del monasterio correspondientes a una población aproximada de noventa monjas. ${ }^{66}$ La religiosa hacía énfasis en la gran ruina ocasionada por el terremoto, e indicaba que actualmente se les daba «4 reales cada semana a cada una y un poquito de frijoles crudos». Por ese motivo, no se explicaba adónde iban a parar las rentas del monasterio que, según sus cálculos, ascendían a unos 30000 pesos. La religiosa, con gran conocimiento probablemente debido a su desempeño como vicaria años antes, estimaba de manera pormenorizada los gastos y costos anuales en 24000 pesos. Dichos gastos incluían, entre otros: 120 panes y 10 carneros diarios; 10 palos de velas y 2 libras de jabón mensuales; aceite para las lámparas de la iglesia; vino; hostias, y gallinas. ${ }^{67}$ Sinforosa culpaba de la mala praxis a la madre Manuela Jáuregui, la madre Poveda y la madre Barbarán, y aconsejaba a Barroeta registrar las cesiones y renegociar los inquilinos «al haber varios rezagos por cobrar».

Además de denunciar estas irregularidades presupuestales, la religiosa nuevamente insistía en la necesidad de reducir el número de criadas: "si ahora no se logra se pondrá todo peor e irremediable». Para ello sugería al prelado solicitar a la abadesa, bajo amenaza de excomunión, una nómina de las que habían quedado en el monasterio. Seguramente esta sugerencia ocasionó que tres días después, el 9 de noviembre, el arzobispo solicitase a la prelada que expulsara a las criadas sobrantes, permitiendo únicamente dos por profesa, y enviara un informe sobre este asunto junto con una lista de las celdas y las personas que en ellas habitaban, detallando por separado si pertenecían a donadas, seglares o criadas.

Al finalizar su misiva, Sinforosa, al igual que Magdalena, señalaba que sus superioras no querían que las profesas dijesen nada, pues sería «desacreditar su casa». Asimismo, contaba que el capellán sospechaba de ella por el largo tiempo que había pasado con el arzobispo durante el interrogatorio privado, e indicaba que no había podido escribir más «por no fiar de nadie», pero que estaba dispuesta a conversar personalmente con Barroeta si necesitaba más información. No creemos que este encuentro personal tuviera lugar, ya que pocos días después, el 13 de noviembre, la religiosa escribía al arzobispo, esta vez agradeciéndole la reforma «de que había tanta necesidad que se hacía inexplicable». ${ }^{68} \mathrm{La}$ religiosa alababa la reducción del número de criadas y enfatizaba la necesidad de esto: «porque mucha gente y ruin se

65 Como podemos observar las denuncias realizadas por Magdalena y Sinforosa en sus misivas son muy similares a las expresadas por las profesas en el interrogatorio particular.

66 AAL. Monasterio de la Concepción, 33: 41.

67 La religiosa indicaba que el precio de la mayor parte de estos objetos había aumentado desde el temblor. Asimismo, incluía pagos a profesionales como el mayordomo, capellán, doctores, abogados y procuradores ascendiendo el total a 23831 pesos.

68 AAL. Monasterio de la Concepción, 33: 42. hace imposible el gobernarlas». Sinforosa reiteraba que dos criadas por religiosa eran más que suficientes y, además, solicitaba que ninguna donada tuviera criadas en adelante. ${ }^{69}$

La profesa aprovechaba para manifestar que habían quedado algunas mestizas como seglares, siendo esto poco conveniente, por lo que solicitaba «que ninguna, que no sea limpia de ninguna raza quede [...] que dan escandalo con su mala vida». ${ }^{70}$ Sinforosa también denunciaba a la seglar Panchita Zegarra, quien, recordemos, ya había sido acusada en el interrogatorio por un par de religiosas, siendo seguramente Sinforosa una de ellas. En su misiva condenaba la "sospechosa» amistad de la seglar con una religiosa, señalando que, aunque cada una vivía en su celda, estaban todo el día juntas. Asimismo, indicaba que había rumores de que una joven profesa estaba «siendo inclinada a las malas costumbres por Zegarra», por lo que solicitaba su expulsión inmediata o, al menos, su aislamiento. También denunciaba por el mismo motivo a otra seglar llamada Gregoria, quien, a su parecer, tenía una relación "demasiada estrecha» con una religiosa, aunque "no tan escandalosa» como la de Zegarra. La última acusada era Sebastiana del Corro, «por estar constantemente fuera de la clausura trayendo y llevando especies». La religiosa pedía que se le prohibiera salir bajo ningún pretexto, lo cual sugería aplicar al resto de seglares: «que ninguna entre ni salga [...] váyanse si se quieren recoger a un beaterio o a las recogidas [...] acá vienen a perderse y perdernos. Las que están que vivan bien y sino que se vayan que menos mal será. Ofendan a Dios en el siglo y no en la religión que son las casas destinadas a la mayor perfección». ${ }^{71}$ La religiosa, para finalizar, justificaba sus acusaciones indicando que no tenía ánimos de perjudicar a nadie, "pero es tanta la relajación que hacen en esto que me obliga a decir la verdad en cumplimiento del precepto». ${ }^{72}$

Por su parte, la abadesa también escribía al arzobispo, pero para informarle del cumplimiento de la mayor parte de lo dispuesto en el auto y brindarle la lista solicitada de habitantes del monasterio. En su misiva indicaba que de las treinta y nueve criadas sin ama, las religiosas se habían apropiado de algunas «por haber despachado a la calle las que tenían pequeñas y quedar con el número de dos que manda Vuestra llustrísima». ${ }^{73}$ Asimismo, la prelada aprovechaba para interceder por las criadas expulsadas, señalando que muchas habían quedado huérfanas y sin refugio: «... no

69 Sinforosa indicaba que hacía aproximadamente ocho años había encargado al misionero fray Joseph de San Antonio, que viajaba a España, sacar una bula que señalase que las religiosas no podían tener más de una criada y que no podían entrar más donadas o seglares. La religiosa había pagado para ello 100 pesos, que comprendían tanto el costo de la bula como un apoyo al misionero. Sinforosa advertía a Barroeta que se había enterado de que las bulas habían llegado hace tres años, y que quizás fueran de utilidad en el marco de su reforma. Ibíd.

70 Sobre la cuestión de las mestizas en el monasterio de la Concepción ver: Pérez Miguel 2019.

71 AAL. Monasterio de la Concepción, 33: 42, 1754. Parece que Zegarra y al menos otras dos seglares fueron expulsadas por su comportamiento.

72 Ibíd.: f. 2 r.

73 Recordemos que esta petición había sido una constante en los interrogatorios. Consideramos, asimismo, que la cifra establecida por Barroeta de dos criadas habría estado influenciada por Magdalena y Sinforosa quienes habían solicitado al prelado que las religiosas se quedasen solo con este número, y que las donadas no pudieran tener ninguna. 
tienen dónde albergarse si se expelen de este monasterio así por su indigencia como por su edad»..$^{74}$ La abadesa solicitaba dispensarlas y permitir que se quedaran en el monasterio. Del mismo modo, negociaba el aumento de criadas que Barroeta había dispuesto para el servicio de la iglesia de cuatro a seis u ocho, argumentando que las que habían quedado eran tan mayores que no podían cumplir con sus obligaciones. Finalmente, pedía la exoneración del «pago de piso" de 50 pesos por parte de las seglares con base en la "estrecha indigencia» que le habían manifestado.

Como podemos observar, la abadesa Rafaela del Molino, a pesar de cumplir varias exigencias del arzobispo, no dudaba en negociar otras, haciendo malabarismos para equilibrar su obligación como súbdita del prelado sujeta a él, con su deber como madre superiora del monasterio y protectora de sus moradoras:

Yo quisiera hacer presente todo lo que se comprime mi ánimo con estos asuntos, pues el mío solo es sacrificar ciega y humildemente mi más pronta obediencia, pero el empleo que indignamente obtengo y las suplicas de mis amadas hermanas me hacen poner en su prudente consideración estos reparos. ${ }^{75}$

La abadesa logró que parte de sus súplicas fueran atendidas, ya que el 29 de noviembre el arzobispo señalaba que: «por representación hecha por la madre abadesa a instancia de diferentes religiosas» se hacía preciso moderar y reformar algunas cosas. De este modo, Barroeta daba trece nuevas disposiciones, gran parte de las cuales eran reformas de las anteriores. ${ }^{76}$ Por ejemplo, permitía que hubiera en la iglesia las seis criadas solicitadas por la abadesa y, aunque no eximía a las seglares del pago, al menos rebajaba a la mitad la cantidad a entregar. Sin embargo, parece que las criadas expulsadas no fueron exoneradas, tal y como se insinúa en otra misiva de Sinforosa Cordero al arzobispo con fecha de 9 de diciembre. ${ }^{77}$

En esta ocasión, Sinforosa contaba al arzobispo que la ausencia de sus misivas se debía a las sospechas que varias profesas tenían sobre ella, aunque las daba por buenas "por que con ese miedo se van remediando". ${ }^{78}$ La monja mostraba su alegría por la reducción de población en el monasterio, lo que disminuía los problemas y posibilitaba un mejor control del centro. En esta ocasión, Sinforosa enviaba un libro de cuentas al prelado para que este pudiese comprobar cómo el dinero de dotes, censos y otros ingresos estaba siendo malversado. La religiosa rogaba discreción sobre el envío, prometiendo avisar a Barroeta de «lo que fuere contra Dios».

Una semana después, otra breve misiva de Sinforosa llegaba hasta las manos del arzobispo..$^{79}$ En ella, la religiosa indicaba que por el momento «no era conveniente dar aviso [...] porque esto solo sirviera de mayor inquietud». Sinforosa señalaba que ella informaría del momento adecuado y

\footnotetext{
74 AAL. Monasterio de la Concepción, 43, 1754. Informe de la abadesa acerca de la reducción de criadas.

75 AAL. Monasterio de la Concepción 33: 43, 1754.

76 AAL. Monasterio de la Concepción, 33:37.

77 AAL. Monasterio de la Concepción, 33: 42, 1754. La religiosa prevenía al arzobispo de que estaban tratando de engañarlo poniendo bajo la nómina de las seglares a criadas sin ama.

78 AAL. Monasterio de la Concepción, 33: 44, 9-12-1754.

79 AAL. Monasterio de la Concepción, 33: 47, 1754.
}

preguntaba a Barroeta si necesitaba explicación del libro de cuentas que le había hecho llegar. No sabemos si el prelado respondía por escrito a las misivas de la religiosa, ya que no nos ha quedado constancia documental. Quizás, para evitar posibles inconvenientes, el arzobispo hacía llegar de manera oral sus comentarios a juzgar por la carta de Sinforosa que indicaba que "podía fiar de palabra al portador», probablemente una de sus criadas de confianza. Es probable que las portadoras de las misivas también hiciesen llegar información oral al prelado.

El 21 de diciembre, a un día de las elecciones de abadesa, Sinforosa escribía nuevamente a Barroeta insistiendo en que ese día revisase las cuentas del monasterio y que prohibiese a la abadesa cobrar las rentas hasta que hiciese una inspección detallada de la contabilidad. ${ }^{80}$ Sinforosa incluso indicaba al prelado cómo proceder. En primer lugar, debía pasar en persona al archivo y solicitar las cuentas actuales y las anteriores. Cuando no se localizasen, debería pedírselas a la secretaria, quien declararía no conocer su paradero. Es en ese momento cuando se las pedirían a Sinforosa, quien las tendría en su poder y se las daría al arzobispo para que las cotejase con las cuentas que previamente le había hecho llegar. ${ }^{81}$ Sinforosa disculpaba a la abadesa de su mala gestión al explicar que "en materia de negocio no entiende, las otras son las que todo lo traen enredado». Asimismo, aprovechaba para insinuar un supuesto interés de varias profesas en que ella fuese elegida nueva abadesa, lo que nos ayuda a entender el énfasis de sus acusaciones sobre el mal gobierno del monasterio.

Precisamente, días antes varias religiosas, de manera anónima, habían hecho llegar un memorial al arzobispo en el que acusaban a las «madres Povedas» de pedir votos para doña Josefa Obregón y Mena a través de medios ilícitos, tales como dinero, promesas de oficios, amenazas e injurias. Las profesas solicitaban nombrar presidenta a Sinforosa Cordero "por su ejemplar vida y talentos y don de gobierno».82 También otra religiosa llamada Tomasa Merlo, mediante una carta particular, hacía la misma petición al arzobispo. ${ }^{83}$ Sospechamos que la promotora de ambas solicitudes habría sido la propia Sinforosa, que trataba de inclinar la balanza a su favor en las futuras elecciones, a lo que se sumaría su campaña de descrédito contra la anterior abadesa y la nueva postulante. ${ }^{84}$ Debemos mencionar brevemente que esta no sería la primera ocasión en la que Sinforosa aspiraba al cargo abacial, siendo la primera en 1745 , cuando fracasó

80 Las elecciones de abadesa en el monasterio de la Concepción se celebraban, y siguen celebrando, el día 22 de diciembre. Era costumbre que el arzobispo estuviera presente ese día. AAL. Monasterio de la Concepción, 33: 50, 1754.

81 Sinforosa había podido acceder a esta información como vicaria de la anterior abadesa, la madre Jáuregui.

82 AAL. Monasterio de la Concepción, 33: 46, 10-12-1754.

83 AAL. Monasterio de la Concepción, 33: 45, 10-12-1754. «Carta que remite Tomasa Merlo de la Fuente al arzobispo de Lima, expresando estar a favor de doña Sinforosa Cordero, quien tiene 30 años de religiosa, en virtud y buen ejemplo, y ha sido dos veces secretaria y vicaria de doña Manuela de Jáuregui».

84 Asimismo, creemos que como parte de su campaña habría solicitado al prelado prohibir a las criadas manifestaciones a favor o en contra de las candidatas, razón por la cual Barroeta en 19 de diciembre habría prohibido: "vítores y alborotos [...] ni menos de dicterios ni libelos so pena de que la que contraviniese a lo mandado será inmediatamente puesta en la calle». 
al ser acusada de «corrupta» por haber «vivido libremente con cierta persona eclesiástica, de quien hubo una hija». ${ }^{85}$ Durante dichas elecciones, un grupo de religiosas escribió al entonces arzobispo para solicitar que prohibiera la postulación de Sinforosa por los motivos señalados. ${ }^{86}$ Dada la gravedad de las acusaciones, Sinforosa fue declarada inhábil hasta comprobarse la validez de las mismas, siendo elegida abadesa Rafaela del Molino, actual prelada del monasterio por segundo y último trienio. Consideramos que parte de las denuncias de Sinforosa formaban parte de una venganza personal, tanto contra la abadesa como contra aquellas que la habían denunciado hacía más de una década, incluido el doctor Poveda, siendo el propósito final de la religiosa acceder finalmente al tan preciado cargo abacial. Ser aliada y confidente del arzobispo sin ninguna duda era una buena manera de acercarse al mismo. De este modo, parece que no era solo la intención de servir a Dios la que empujaba las denuncias de Sinforosa contra el gobierno de la actual prelada, sino también la búsqueda de su báculo. ${ }^{87}$ Sin embargo, su estrategia no tuvo el resultado esperado, ya que la elegida para el cargo fue doña Josefa Obregón y Mena.

Volvemos a tener noticias de Sinforosa el 27 de diciembre, lamentándose amargamente del desorden existente tras la votación. ${ }^{88}$ En su carta, la monja se quejaba de que las criadas cantaban coplas y hacían ruidos en la puerta de su celda hasta las diez de la noche sin que nadie las contuviera: "haciendo bailes enlistonadas con faldellines de seda y zarcillos contra lo mandado». La religiosa también denunciaba que gran parte de las criadas expulsadas había regresado al monasterio, al igual que una seglar "de mal ejemplo» llamada María Ormanza, quien se «ejercita solo en amistades ilícitas y pleitos y creo le dura una pasión con personas de esta religión». Sinforosa solicitaba una actuación contundente por parte del prelado. Asimismo, la profesa se quejaba de que seguía bajo sospecha de dar información, por lo que la abadesa había prohibido que su criada de confianza, Dominga, dejara la clausura, acusándola de contar lo que sucedía en el monasterio. Así, la religiosa pedía a Barroeta que ordenara dejar salir a su criada.

85 Dicho eclesiástico sería don Valentín Velásquez Tineo, cura difunto de Atavillos, quien habría pagado la dote, ajuar y celda de doña Sinforosa que, además, habría sido su heredera tras su muerte. Al parecer Valentín Velázquez había costeado todos los gastos de la profesa "con notable abundancia». Asimismo, había dotado a la supuesta hija de ambos para su ingreso en el monasterio. Esta hija, llamada Jose$\mathrm{fa}$, había pasado su infancia en el monasterio de Santa Clara bajo e nombre de Josefa del Espíritu Santo, ingresando posteriormente en la Concepción donde residía en la misma celda que Sinforosa. Al ingresar en la Concepción habría mentido sobre su legitimidad señalando que era hija legítima de don Fermín Gutiérrez y de doña María López. AAL. Monasterio de la Concepción, 33: 7, 1745-46.

86 Debido a que el arzobispado estaba vacante los miembros de Cabildo Metropolitano ordenaron que la carta fuera remitida al provisor y vicario general para que se procediera según lo conveniente, constando la firma del doctor Poveda.

87 Durante el interrogatorio realizado a partir de la denuncia a Sinforosa, un testigo había destacado la ostentación de la celda en que la religiosa vivía, por lo que no consideramos que fuera únicamente su celo por el cumplimiento de las reglas y un deseo de perfección religiosa lo que la habría llevado a trasladar sus denuncias a Barroeta, sino, más bien el deseo de contar con su respaldo en su eventual candidatura a abadesa y evitar los problemas acaecidos en 1745 .

88 AAL. Monasterio de la Concepción, 33: 51, 1754.
No sabemos qué sucedió con Dominga o si el arzobispo moderó el comportamiento de las internas tras las elecciones, ya que la siguiente misiva que tenemos de la religiosa a Barroeta corresponde a febrero de $1755 .{ }^{89}$ En ella, Sinforosa continuaba denunciando las malversaciones de las rentas del monasterio y la presencia de criadas y esclavas que no habían sido expulsadas tal y como el prelado había ordenado. ${ }^{90} \mathrm{Te}-$ nemos una última misiva de Sinforosa al arzobispo Barroeta con fecha de 15 de mayo de 1755 acerca de problemas con la alimentación de las profesas, entre otras cuestiones. ${ }^{91}$ No descartamos que se hubiera comunicado previamente con él en relación a este asunto, ya que el 29 de febrero el arzobispo había solicitado a la nueva abadesa un informe acerca de los gastos de las religiosas para su sustento diario..$^{92}$

Asimismo, no creemos que esta fuera su última comunicación, tanto escrita como oral, con este y posteriores prelados, máxime considerando que Sinforosa finalmente llegaría a ser abadesa del monasterio de la Concepción desde 1763 a 1766 . Por lo que no descartamos su interacción con Diego Antonio de Parada, quien fue arzobispo durante su prelacía y que también fue el responsable de una visita general a los monasterios limeños femeninos.

\section{IMAGEN 3}

\section{Retrato de la abadesa doña Sinforosa Cordero y Espinosa}

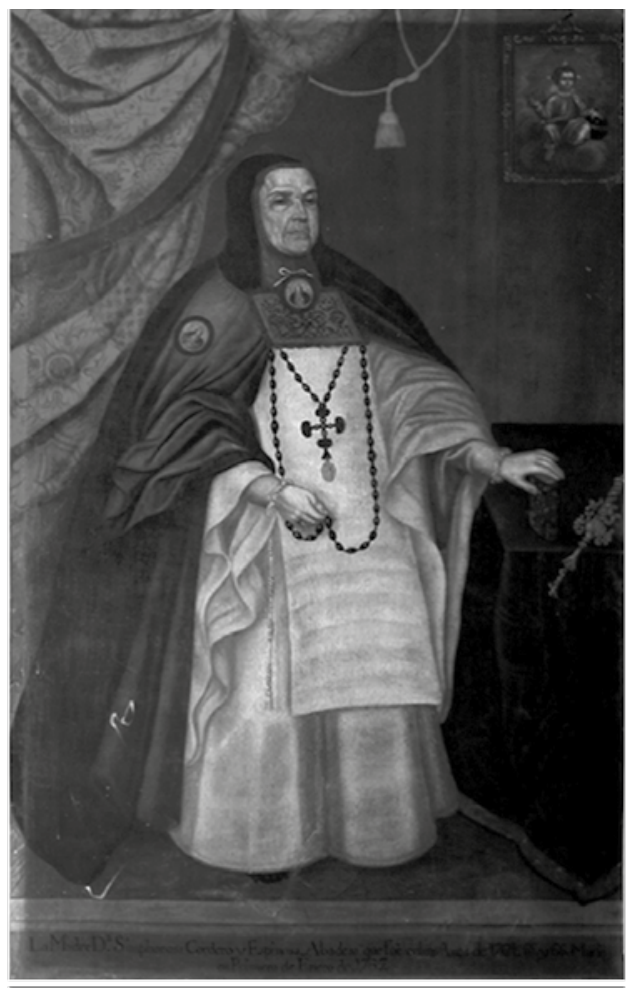

Fuente: AHMCL. Anónimo. S. XVIII. La madre doña Sinphorosa Cordero y Espinosa, abadesa que fue en los años 1764, 65 y 66, murió el 1 de enero de 1767.

89 AAL. Monasterio de la Concepción, 33: 53, 20-02-1755.

90 Sinforosa relataba que una religiosa que tenía dos criadas adultas y dos niñas esclavas - propiedad de un mercader llamado Pascual- le había avisado de las disposiciones de Barroeta y este, con conocimiento y apoyo de la abadesa, las había acogido hasta que retornaron al día siguiente al monasterio (Ibíd.).

91 AAL. Monasterio de la Concepción, 33: 54, 15-05-1755.

92 AAL. Monasterio de la Concepción, 33: 52, 29-02-1755. 


\section{CONCLUSIÓN}

Las visitas y los autos arzobispales frutos de las mismas suponen un asunto de gran interés e importancia al poner de relieve la incapacidad de los diversos estatutos y reglas de cada monasterio para mantener la disciplina esperada en el interior de las instituciones. Del mismo modo, nos permiten profundizar en aspectos como el conjunto de valores morales de la época o las tensiones subyacentes entre estos centros y las autoridades coloniales eclesiásticas y civiles o sus propias internas. Los documentos resultantes de las visitas arzobispales reflejan la dicotomía entre la utopía de la vida conventual y la realidad de la vida diaria, y nos posibilitan observar las complejas dinámicas del interior de los monasterios, así como los destacados roles desarrollados por los actores involucrados en el proceso de regulación de estos centros. De este modo, las profesas y otras habitantes dejan de ser meras receptoras de legislación, constituyéndose, por el contrario, en activas constructoras de normatividad que no dudaron en hacer uso de diversas estrategias, como cartas privadas al arzobispo, para defender sus intereses.

Más allá de si dichos intereses eran personales - tales como rencillas entre las religiosas, deseos de revancha o de una prelacía - o relativos al funcionamiento del centro, debemos evaluar la importancia tanto de la información facilitada por las profesas como el uso de la misma por parte del arzobispo para la elaboración de normatividad destinada a la regulación y control del monasterio y sus moradoras. Asimismo, hemos de enfatizar el papel mediador de la abadesa y su capacidad para negociar las disposiciones de sus superiores eclesiásticos y defender los intereses de su comunidad, logrando cambiar y revocar de manera exitosa, varias de las disposiciones. ${ }^{93}$ Finalmente, debemos destacar la preocupación de las autoridades por el control y funcionamiento de estos centros, estos «conventos grandes o pequeñas repúblicas», piezas centrales, sin duda, en los engranajes de la monarquía hispánica.

\section{FUENTES}

Ballesteros, Manuel. 1943. La Iglesia de España en el Perú. Colección de Documentos para la Historia de la Iglesia en el Perú, que se encuentran en varios archivos, dir. Emilio Lisson. Vol.1. Sevilla: Católica Española.

Juan, Jorge y Antonio de Ulloa. 1991 [1749]. Noticias secretas de América, editado por Luis J. Ramos Gómez. Madrid: Historia 16.

Mendiburu, Manuel de. 1876. Diccionario histórico-biográfico del Perú. Tomo 2. Lima: Imprenta de J. Francisco Solís.

Murillo Velarde, Pedro. [1791]. Cursus juris canonici, hispani, et incidi in quo, juxta ordinem titularum decretalium non solum canonicae decisiones, 3a ed. Matriti: Typografhia Ulloae a Romane Ruíz.

Tercer Concilio Limense (1583-1591). 2017. Edición Luis Martínez Ferrer. Lima: Facultad de Teología Pontificia y Civil de Lima - Universidad Pontificia de la Santa Cruz - Ediciones San Pablo.

\section{BiBLIOGRAFÍA}

Acosta, Antonio. 2014. Prácticas coloniales de la Iglesia en el Perú. Siglos XVI y XVII. Sevilla: Aconcagua Libros.

93 No fueron escasas las ocasiones en que las preladas enfrentaron a sus autoridades eclesiásticas, incluso ante los tribunales.
Arias Cuba, Ybeth. 2009. Cuerpo y poder en los monasterios limeños durante la época borbónica: la Encarnación y la Concepción (17501821). Tesis de Magíster. Universidad Nacional Mayor de San Marcos.

Armas Asín, Fernando, ed. 1999. La construcción de la Iglesia en los Andes (ss. XVI-XX). Lima: Pontificia Universidad Católica del Perú.

Armas Medina, Fernando de. 1053. Cristianización del Perú (15321600). Sevilla: Escuela de Estudios Hispano-Americanos.

Barrio, Maximiliano. 2010. El clero en la España Moderna. Córdoba: CajaSur.

Borges, Pedro, ed. 1992. Historia de la Iglesia en Hispanoamérica y Filipinas (siglos XV-XIX). 2 vols. Madrid: Biblioteca de Autores Cristianos.

Burns, Kathryn. 2008. Hábitos coloniales: los conventos y la economía espiritual del Cuzco. Lima: IFEA.

Campos, Francisco Javier. 2011. «Monacato femenino y recolección. Ntra. Sra. del Prado de Lima: fidelidad y crisis del Setecientos (1650-1800)». En La clausura femenina en el Mundo Hispánico. Una fidelidad secular. Madrid: Real Centro Universitario EscorialMaría Cristina.

Candau Chacón, María Luisa. 1998. «Instrumentos de modelación y control: el Concilio de Trento y las visitas pastorales (la Archidiócesis Hispalense, 1548-1604)». En Felipe II (1527-1598): Europa y la monarquía católica, vol. III, 159-177. Madrid: Parteluz.

Carrillo, Gonzalo Alberto. 2018. Las redes de sociabilidad de los oidores de Lima. Cultura política, redes clientelares y gestión del poder en Lima virreinal (1745-1761). Tesis de magíster. Pontificia Universidad Católica del Perú.

Contreras, Ray Mitchell. 2011. «"Las esposas de Jesucristo implorando perdón al cielo": las religiosas de los monasterios limeños frente a los movimientos telúricos en los siglos XVII y XVIII». En Trabajos de historia: religión, cultura y política en el Perú, siglos XVII-XX, 75-92. Lima: UNMSM.

Chowning, Margaret. 2005. Rebellious Nuns. The Troubled History of a Mexican Convent, 1752-1863. Oxford - New York: Oxford University Press.

Danwerth, Otto, Benedetta Albanwi y Thomas Duve, eds. 2019. Normatividades e instituciones eclesiásticas en el virreinato del Perú siglos XVI-XIX. Frankfurt am Main: Max Planck Institute for European Legal History. https://doi.org/10.12946/gplh5

Duve, Thomas. 2012. Información bibliográfica para el estudio del Derecho Canónico Indiano. Junín: Ediciones de las Tres Lagunas.

Egaña, Antonio de, S.J. 1966. Historia de la Iglesia en la América española, desde el Descubrimiento hasta comienzos del siglo XIX. Hemisferio sur. Madrid: Editorial Católica.

Estenssoro Fuchs, Juan Carlos. 2003. Del paganismo a la santidad: La incorporación de los indios del Perú al catolicismo, 1532-1750. Lima: Instituto Francés de Estudios Andinos - Pontificia Universidad Católica del Perú.

Fraschina, Alicia. 2008. «Reformas en los conventos de monjas de Hispanoamérica: 1750-1865. Cambios y continuidades». Hispania Sacra LX 122: 445-466. https://doi.org/10.3989/hs.2008.v60.i122.63

Laserna Gaitán, Antonio Ignacio. 1995. «El último intento de reforma de los monasterios femeninos en el Perú colonial: el auto del arzobispo Parada de 1775». Anuario de estudios americanos LII, 2: 63-287. https://doi.org/10.3989/aeamer.1995.v52.i2.457

Latasa, Pilar, coord. 2003. Reformismo borbónico y sociedad en la América borbónica. In memoriam Ronald Escobedo. Pamplona: EUNSA.

Lynch, John. 1996. «El reformismo borbónico en Hispanoamérica». En El reformismo borbónico. Una visión interdisciplinaria, ed. Agustín Guimera. Madrid: Alianza.

Lynch, John. 2012. New Worlds: A Religious History of Latin America. London: Yale University Pressm.

Lavrin, Asunción. 1965. "Ecclesiastical Reform of Nunneries in New Spain in the Eighteenth Century». The Americas XXII, 2: 182-203.

Lavrin, Asunción. 2006. Las esposas de Cristo. La vida conventual en la Nueva España. México: Fondo de Cultura Económica. 
Martínez Martín, Carmen. 2008. «El Ilmo. Pedro Ao Barroeta y Ángel: un conflictivo arzobispo en la Iglesia de Lima (1751-1758)». Berceo 154: 139-172.

Mayer, Alicia y José de la Puente Brunke, eds. 2015. Iglesia y sociedad en la Nueva España y el Perú: Pamplona: Anaya.

Moreno Cebrián, Alfredo, ed. 1983. Superunda, José A. Manso de Velasco, Conde de. Relación y documentos de gobierno del Virrey del Perú. Madrid: CSIC.

Moreno Cebrián, Alfredo. 2000. El Virreinato del Marqués de Castelfuerte, 1724-1736: el primer intento borbónico por reformar el Perú. Madrid: Catriel.

Moreno Cebrián, Alfredo. 2003. «El regalismo Borbónico frente al poder vaticano acerca del estado de la iglesia en el Perú durante el primer tercio del siglo XVIII». Revista de Indias LXIII, 227: 223-274. https://doi.org/10.3989/revindias.2003.i227.438

O'phelan Godoy, Scarlett. 1988. «Las reformas borbónicas y el contexto de la Gran Rebelión». En Un siglo de rebeliones anticoloniales: Perú y Bolivia 1700-1783. Cuzco: Centro de Estudios Rurales Andinos «Bartolomé de las Casas».

O’phelan Godoy, Scarlett. 1995a. La gran rebelión en los Andes: de Túpac Amaru a Túpac Catari. Cuzco: CBC.

O'phelan Godoy, Scarlett. 1995b. La gran rebelión en los Andes: De Túpac Amaru a Túpac Catari. Cuzco: Centro de Estudios Regionales Andinos Bartolomé de las Casas.

O'phelan Godoy, Scarlett. 2003. «El vestido como identidad étnica e indicador social de una cultura material». En El Barroco Peruano II, ed. Ramón Mujica Pinilla, 99-133. Lima: Banco de Crédito del Perú.

O'phelan Godoy, Scarlett. 2007. «La moda francesa y el terremoto de Lima de 1746». Bulletin de l'Institut français d'études andines 36 (1): 19-38. https://doi.org/10.4000/bifea.4595

O'phelan Godoy, Scarlett, comp. 2015. El Perú en el siglo XVIII: la era borbónica. Lima: Pontificia Universidad Católica del Perú - Fundación M. J. Bustamante.

Pérez- Mallaina, Pablo Emilio. 2001. Retrato de una ciudad en crisis. La sociedad limeña ante el movimiento sísmico de 1746. Sevilla: CSIC - PUCP - Instituto Riva-Agüero.

Pérez-Miguel, Liliana. 2019. «Entre normas y particularidades. El caso del Monasterio de la Concepción de la Ciudad de los Reyes». En Normatividades e instituciones eclesiásticas en el virreinato del
Perú siglos XVI-XIX, 135-172. Global Perspectives on Legal History, 12. Frankfurt am Main: Max Planck Institute for European Legal History.

Seiner, Lizardo. 2009. Historia de los sismos en el Perú. Catálogo: Siglos XV-XVII. Lima: Universidad de Lima.

Serrera, Ramón María. 2009. Mujeres en clausura: macroconventos peruanos en el barroco. Sevilla: Universidad de Sevilla.

Traslosheros, Jorge. 2016. "Introduction: Canon Law and its Practice in Colonial Latin America». The Americas 73 (1): 3-11.

Traslosheros, Jorge y Ana de Zaballa Beascoechea, eds. 2010. Los indios ante los foros de justicia religiosa en la Hispanoamérica virreinal. México: UNAM.

Vargas Ugarte, Rubén. 1960. Un monasterio Limeño. Lima: Sanmarti.

Vargas Ugarte, Rubén. 1961. Historia de la Iglesia en el Perú (17001800). Tomo IV. Burgos: Imprenta Santa María.

Vargas Ugarte, Rubén. 1951-1954. Concilios Limenses (1551-1772). Lima: Tipografía Peruana

Vargas Ugarte, Rubén. 1953-1962. Historia de la Iglesia en el Perú, 5 vols. Burgos: Imprenta Santa María.

Viforcos Marinas, María Isabel. 1995. «Las reformas disciplinares de Trento y la realidad de la vida monástica en el Perú virreinal». En El Monacato Femenino en el Imperio Español. Monasterios, beaterios, recogimientos y colegios, coord. Manuel Ramos Medina, 523535. México: CONDUMEX.

Viforcos Marinas, María Isabel. 2005. «Las monjas en los concilios y sínodos celebrados en las iglesias del virreinato peruano durante la época colonial». En Fundadores, fundaciones y espacios de vida conventual: nuevas aportaciones al monacato femenino, coord. María Isabel Viforcos Marinas y María Dolores Campos SánchezBordona, 673-704. León: Universidad de León.

Vivero, Domingo de. 1892. Galería de retratos de los arzobispos de Lima (1541-1891). Lima: Imprenta y Litografía de la «Librería clásica y científica».

Walker, Charles. 2012. Colonialismo en ruinas: Lima frente al terremoto y tsunami de 1746. Lima: IEP.

Zaballa Beascoechea, Ana de, ed. 2012. Los indios, el Derecho Canónico y la justicia eclesiástica en la América virreinal. Madrid Frankfurt am Main: Ibero- Americana - Vervuert. 